\title{
Les Lumières de Hong Kong and the mist of translation
}

French versions of two contemporary Chinese novels

Nicolas Zufferey

\section{OpenEdition}

\section{Journals}

Édition électronique

URL : http://journals.openedition.org/chinaperspectives/262

DOI : $10.4000 /$ chinaperspectives. 262

ISSN : 1996-4617

\section{Éditeur}

Centre d'étude français sur la Chine contemporaine

Édition imprimée

Date de publication : 15 avril 2003

ISSN : 2070-3449

\section{Référence électronique}

Nicolas Zufferey, «Les Lumières de Hong Kong and the mist of translation », China Perspectives [En ligne], 46 I march-april 2003, mis en ligne le 29 août 2006, consulté le 28 octobre 2019. URL : http:// journals.openedition.org/chinaperspectives/262 ; DOI : 10.4000/chinaperspectives.262

Ce document a été généré automatiquement le 28 octobre 2019

(c) All rights reserved 


\title{
Les Lumières de Hong Kong and the mist of translation
}

French versions of two contemporary Chinese novels

\author{
Nicolas Zufferey
}

\section{NOTE DE L'ÉDITEUR}

Translated from the French original by Nick Oates

1 Over the past few years, a large number of works of contemporary Chinese literature, primarily novels, have been translated into French, and several publishers (Picquier, Actes Sud, Bleu de Chine, les éditions de l'Aube, Gallimard-Folio, etc.) are proving to be very active in this domain. This is certainly a good thing. The translations that they have published allow a readership previously unfamiliar with China and its literature to gain at least some idea of the richness of contemporary creation in that country. This wave of translations is the result of several factors, the first of which, and the most important, is that the Chinese literary scene produced works in the 1980s and 1990s of undeniable sociological and literary value.

2 Most certainly, the literary field in the years from 1949 to 1976 in the People's Republic was not as sterile or as monotone as is often thought. A number of texts by official authors are worth saving, in particular some examples of the literature of the soil, or Stories From the Concentration Camp at Auschwitz (Aosiweixin jizhongying de gushi) by Ba Jin. And in recent years there has been an increasing interest in the "hidden creation" (qianzai chuangzao) of this period, that is the underground literature-in particular the strange 30 May at 10 o'clock, Peking Dormitory (Wuyue sa xia shidian Beiping sushe, 1949) by Shen Congwen, or even The Second Handshake (Di'er ci woshou), written secretly by Zhang Yang during the Cultural Revolution.

3 Nevertheless, the political climate during those thirty-odd years did not favour literary creation, and this period cannot rival either the literature of the Republican era or that of the last two decades of the twentieth century. When it comes to this last period, the 
profusion is veritably prodigious, and a number of works are of high quality: no doubt some of these texts will be passed on to future generations and deserve to be inducted into the world's literary heritage. This quality, let us underline in passing, is not solely explained by the opening up of China and the country's political liberalisation, by Western influence or by the greater latitude of expression allowed the authors. It is also one of the effects of the years of the Cultural Revolution, which for a number of current Chinese writers was a tragic yet at the same time formative period, seminal even-and in many cases the occasion of a painful but fecund reflection on human nature and the relation of the individual to power and to society.

The quality of the works is not sufficient in itself, however, to explain this wave of translations in France. It is also necessary for these translations to fulfil an expectation of the public. Perhaps there also needs to be a form of official recognition (of which the Nobel Prize awarded to Gao Xingjian is the most striking example), but this recognition generally accompanies or amplifies the interest of readers rather than causing it. How can this interest of the public be explained? By the need to understand a civilisation that has remained closed for too long, that is often considered, though probably mistakenly, as fundamentally different, and that one suspects might come to play an absolutely central role in tomorrow's world? By that taste for exoticism and cultural cross-breeding that is so characteristic of our times? Or is it quite simply one of those phenomena of fashion? This is not the place to attempt a reply to this question, but one element in an explanation could be the westernisation of Chinese literature of the twentieth century in general and during the last couple of decades in particular: even if this literature remains "exotic" in some respects, it is no longer totally strange or foreign, and by that fact it may seduce a wider public in the West.

In his excellent Petit précis à l'usage de l'amateur de littérature chinoise contemporaine (Arles, Editions Philippe Picquier, 2002), Noël Dutrait relates the judgement of the famous popular writer Jin Yong, in which he states that modern Chinese literature was "only foreign literature translated into Chinese" (p. 115). This claim seems excessive, but a certain westernisation of themes and forms in modern and contemporary Chinese literature cannot be denied. Indeed, this westernisation is linked to the progressive westernisation of Chinese society in general, particularly in the cities, but also to the Europeanisation of the Chinese language itself, notably in its vocabulary.

When it comes to translation, this westernisation produces significant effects. The principal one concerns the core problem of translation: faithfulness to the original. A translation certainly tends to "betray" the original text less when the cultural distance between the two traditions in question is smaller. And it is certainly more workable to render in French not only the substance but also the atmosphere, the spirit, the style even, of a contemporary Chinese novel than is the case for a classical Chinese work.

But if this possibility exists a priori, it is however necessary that translators arm themselves with the means to achieve this goal. Unfortunately, this is not always the case. Alongside some good exponents of the art, who possess not only the required technical skills, but also a genuine literary sensibility, one encounters many translators who have been inadequately schooled, with the consequence that a number of translations of recent Chinese novels leave much to be desired. Fortunately, the defects of the translation do not always outweigh its principal merit-the fact that it exists (after all, and with all due deference to some, it is undoubtedly better to have an 
imperfect translation than no translation at all). But in certain cases the problems are serious, and the translation becomes a betrayal.

8 As an example of a truly inadequate translation into French, I have chosen the beautiful novel by Wang Anyi, Xianggang qing yu ai (1994, though the preface to the French translation indicates 1995), published by Philippe Picquier in 2001 under the title Les Lumières de Hong Kong (The Lights of Hong Kong). In this case, the weakness of the translation is even more regrettable, as no other work by Wang Anyi has yet been translated into French, while Wang Anyi is certainly one of the major figures in contemporary Chinese literature, and the novel in question, though neither the most well known nor the most representative of her works, perfectly reflects the nature and subtlety of her style.

The main subject of Xianggang qing yu ai is the city of Hong Kong itself, and the novel gives a very good account of its atmosphere and its particular character as a city of passage. The hero, Lao Wei (literally "Old Wei"), is a man in his late forties or early fifties who lives in the United States but who regularly spends a few days in this metropolis as a form of "R\&R", as well as to maintain some amorous relationships. I am here going to examine the translation of an extract taken from the middle of the opening chapter that deals with one of these relationships, with a young woman called Kaidi. Here is the Chinese text and the version taken from Les Lumières de Hong Kong (p. 14):

Laowei et elle devinrent par la suite amis. Peu à peu, celui-ci apprit que ce qu'elle lui avait dit sur elle-même et ses expériences amères était entièrement vrai. Elle s'appelait Kaidi. Il garda l'impression que, dans son histoire, tout n'était pas clair. A compter de cette nuit-là, ils en passèrent bien d'autres ensemble. Ils restaient éveillés d'un bout à l'autre et se retrouvaient confrontés à la réalité du soleil qui se levait, des gens qui sortaient dans la rue. Laowei appréciait que Kaidi ne lui demande pas de se comporter en homme viril pour tout, il était si banal que les Chinoises du continent réagissent ainsi. D'ailleurs, elle n'avait pas de grandes théories à étaler, et c'était tout juste si elle se laissait aller à exprimer son point de vue sur les choses. Bizarrement, cela faisait naître chez lui une réelle compassion à son égard. Laowei appartenait à cette génération plutôt vieux jeu où les hommes considèrent que, sur le plan des relations amoureuses, les femmes seront toujours les uniques victimes. Aussi essayait-il de se conduire d'une tout autre manière avec elle. Un soir, ils montèrent au sommet du HH Center, au restaurant panoramique tournant, pour boire un verre et admirer le spectacle qu'offre de nuit la vue sur Hong Kong. A leur arrivée, le restaurant faisait face à la portion de la baie plongée dans l'obscurité. Dans cet écrin, ils pouvaient laisser libre cours à leur tendresse mutuelle. Mais, malgré tout, de tels sentiments étaient vains. Laowei considérait Kaidi comme sa relation de cœur avérée, et pourtant elle ne possédait pas l'essence de l'accord qu'il cherchait. Elle était devenue le bouquet de fleurs qui garnissait son vase de poterie artisanale et il était tragiquement amoureux.

[Laowei and she eventually became friends. Gradually, he learned that what she had told him about herself and her bitter experiences was totally true. She was called Kaidi. The impression stayed with him that, in her story, not everything was clear. From that night on, they spent many others together. They stayed awake from dusk till dawn, finding themselves confronted by the reality of the sun as it rose, of people going out into the streets. Laowei appreciated that Kaidi did not ask him to behave like a virile man all in all, it was so banal that the mainland Chinese reacted like that. Moreover, she did not have any great theories to expound, and it was as much as she could do to express her point of view on anything. Bizarrely, that gave rise in him to a real compassion for her. Laowei belonged to that rather oldfashioned generation where the men believe that, when it comes to love affairs, the 
women will always be the only victims. Thus he tried to behave in a completely different manner with her. One evening, they ascended to the top of the HH Center, to the panoramic revolving restaurant, to have a drink and admire the spectacular view that the night offers of Hong Kong. When they arrived, the restaurant was facing that part of the bay that was shrouded in darkness. In this jewellery case, they could give free rein to their mutual tenderness. But, despite everything, such feelings were vain. Laowei looked on Kaidi as his avowed and heartfelt love, but she did not possess the essence of harmony that he was looking for. She had become the bouquet of flowers that adorned his handcrafted pottery vase and he was tragically in love.]

This passage is interesting, for it accumulates faults that can be found fairly frequently in translations of Chinese novels. The translation suffers from errors and inaccuracies and clumsy and vague turns of phrase. "Expériences amères "("Bitter experiences") for zaoyu has undoubtedly been taken straight out of the Dictionnaire chinois-français (Han Fa cidian, Peking, Shangwu yinshuguan, 1995, p. 888), but it translates badly in French; "épreuves» ("hardships") would have sufficed in the context. «Ils restaient éveillés d'un bout à l'autre et se retrouvaient confrontés à la réalité du soleil qui se levait, des gens qui sortaient dans la rue " ("They stayed awake from dusk till dawn, finding themselves confronted by the reality of the sun as it rose, of people going out into the street") is incorrect; here, zouren is a verb (in Cantonese) that means "se quitter " ("to part"). And the idea of a "confrontation with reality" is absent from the Chinese text. Similarly absent, in the following sentence, is the idea of "virile" behaviour; the meaning is that Kaidi does not ask him to support her or make their relationship official, possibly by marriage. "Les Chinoises du continent» ("mainland Chinese women"), for Zhongguo nü haizi, literally "Chinese girls", is an interpretation, not a translation. In Hong Kong and Taiwan, the word dalu, the "mainland", is explicitly used to talk about mainland China, and that is how Wang Anyi herself refers to China in the book (notably a few pages further on at the end of Chapter One-a passage in which, we note in passing, the translator renders dalu with a very formal "République Populaire de Chine » ("People's Republic of China") which is not at all in keeping with the tone of the narrative). "Grandes théories à étaler " ("great theories to expound") is too vague a translation, the idea simply being that the few demands made by Kaidi on Lao Wei are not motivated by any ideas, feminist or otherwise, that she may have on relationships between men and women. The word «bizarrement " ("bizarrely") two sentences further on seems both too strong and too vague for fandao, which literally means, "however", or "on the contrary". Similarly vague is the translation « il essayait de se conduire d'une toute autre manière " ("he tried to behave in a very different manner"), where it is obvious that he has stopped having sex with her (bu zuo zhei zhong shi). They do not ascend " un soir " ("one evening") to the top of the HH Center, but "from time to time" (you de shihou)-the mood is iterative. The feelings between them are not "vains", but vague, undecided, unreal. Further on, " considérer comme sa relation de cœur avérée » ("look on as his avowed and heartfelt love") is too strong a translation for shi wei zhiji, which means «considérer comme son ami(e) intime» ("look on as a close friend"). As for the last sentence, the translation put forward quite simply does not mean anything: «le bouquet de fleurs qui garnissait son vase de poterie artisanale " ("the bouquet of flowers that decorated his handcrafted pottery vase") is comical, and Lao Wei is certainly not «tragiquement amoureux " ("tragically in love") with Kaidi ; for that matter, it is impossible to see to what characters in the Chinese original these words might correspond. 
11 As for the name of the male protagonist, Lao Wei, literally "Old Wei", the translator has elected to leave it as it is, a perfectly defensible choice, as the word "vieux " ("old") in French has connotations different from the Chinese lao (particularly when this is used in a proper name). But on the other hand, Lao Wei's age is an important dimension of the narrative, and it is undoubtedly not without significance that the author has decked her character out with this nickname. Let us note in passing that the young lady's name, Kaidi (Kaiti?), is interesting and would perhaps have merited a footnote, if only because it is a homophone of a name voluntarily taken by courtesans.

12 Fundamentally, the version drawn from Les Lumières de Hong Kong suffers from what could be called a «lack of agglomeration», that is a lack of cohesion, or of a binding mass, between the sentences and the parts of speech. This is a defect that can be found in numerous translations of chinese (and is even more true of translations of classical Chinese). We know that a number of modal or syntactical markers, present in principle in Western languages, are only implicit in Chinese, or, at most, sparingly used. This is the case with verb tenses, genders, or person, which are often only indicated by the context. And we can confirm the same phenomenon for certain co-ordinating conjunctions, which do exist in Chinese but are used in a less systematic way than in Western languages. Of course, that is not to say that differences of mode do not exist in Chinese, but quite simply that they are less formalised in Chinese grammar (as Abel Rémusat indicated to Wilhelm von Humboldt in their famous correspondence back in the nineteenth century). This obviously has implications for the translator. A phrase such as Ni bu qu, wo ye bu qu is perfectly natural in Chinese, but the literal translation "You do not go, I do not go either" is less normal than the explicitly conditional form "If you do not go, I will not go either". In Wang Anyi's text that we are commenting on here, the problem is evidently not so simple, but it is clear that a major weakness of the translation derives from the fact that a number of modal phenomena implicit in the Chinese are inadequately or poorly rendered in the French. The verb tenses, in the French version, are badly chosen on several occasions, and the links between the sentences are often badly interpreted. In the translation that I propose below, words and expressions such as «et pourtant" ("and yet"), «alors» ("while"), «lorsque» ("when"), «à ce sujet» (on this subject"), etc., seem to me to provide the binder that is indispensable for the passage to read well and smoothly in French.

of course, criticism is easy, and the criticism of a translation even more so; it is evident that a translator is subject to constraints and cannot spend too much time on each passage. Publishers have a great responsibility here, perhaps not granting sufficient time to their translators and above all not exercising proper control of the translations that are submitted to them. In the case of Les Lumières de Hong Kong, a large part of the defects of the French version can undoubtedly be attributed to excessive haste; time is needed to produce a successful translation. The deficiencies mentioned above are to a large degree the consequence of a lack of reflection on the very sense of the text. The result is an assortment of sentences that exist alongside each other, translated more or less correctly in themselves, but without regard to integrating them in a context. Rather than enjoying a logically structured text, the reader has the feeling that he or she is dealing with a succession of independent statements, atoms of sense that have been too loosely agglomerated. 
By way of comparison, I propose the following translation, which is far from the finished article, but which is certainly much more faithful to the sense of the original:

Par la suite, elle et Vieux Wei devinrent amis. Peu à peu, il comprit que ce qu'elle lui avait dit de sa vie et de ses épreuves était entièrement vrai ; elle s'appelait Kaidi. Et pourtant, il éprouvait quand même un sentiment d'irréalité. Plus tard, ils passèrent plusieurs autres nuits ensemble, et à chaque fois c'étaient de vraies nuits où l'on ne se quitte qu'au lever du jour.

Vieux Wei appréciait le fait qu'elle ne lui demande jamais de la prendre en charge, comme le faisaient habituellement les jeunes filles chinoises. Sur ce sujet, elle n'avait pas la moindre théorie, et n'exprimait jamais son point de vue, mais cela éveillait un sentiment de tendresse chez Vieux Wei. Après tout, il appartenait à cette génération d'hommes un peu vieux jeu qui considèrent que, dans les histoires d'amour, c'est toujours la femme qui est la victime. Alors, il renonça à son aventure avec elle, se contentant de l'emmener de temps à autre au restaurant tournant du Center HH pour y boire un verre en admirant le spectacle de Hong Kong la nuit. Lorsque le restaurant faisait face à cette partie plus sombre de la baie, un sentiment de tendresse sincère montait doucement entre eux, mais cette tendresse avait quelque chose d'évanescent. Il la considérait comme une amie intime, mais elle n'était pas la relation fixe qu'il recherchait - elle était pour lui comme un bouquet dans un vase de terre, comme une grande fleur belle et triste.

[As time went by, she and old Wei became friends. Gradually he came to understand that what she had told him of her life and of her hardships was entirely true; she was called Kaidi. And yet he nevertheless experienced a feeling of unreality. Later, they spent several more nights together, and each time those were genuine nights when you do not part until the break of day.

Old Wei appreciated the fact that she never asked him to take responsibility for her, as Chinese girls so habitually did. She did not have the slightest theory on this subject and never expressed her point of view, but that awoke in Old Wei a feeling of tenderness. After all, he belonged to that rather old-fashioned generation of men who consider that, in love stories, it is always the woman who is the victim. Thus he gave up his affair with her, content enough to take her from time to time to the revolving restaurant at the top of the $\mathrm{HH}$ Center, to have a drink there while admiring the spectacle of night-time Hong Kong. When the restaurant faced the darkest part of the bay, a genuine feeling of tenderness rose gently between them, but this tenderness had something evanescent about it. He considered her a close friend, but she was not the steady relationship that he was looking for-she was to him like a bouquet in a clay vase, a beautiful but sad flower.]

We also note in passing that some of the translation errors in Les Lumières de Hong Kong derive from a lack of consideration that turns of phrase from classical Chinese continue to survive in the modern language. Thus, on page 96 of the translation, the phrase: « Il comptait même communiquer à quelques proches leur numéro de téléphone à Beijiao", i. e., "He was even counting on passing on their telephone number in Beijiao to some close friends", instead of "He passed on their telephone number in Beijiao to some close friends", manifestly results from a poor interpretation of the particle jiang. Although this particle does indeed generally indicate the future in modern Chinese, it must here be read as an equivalent of $b a$ introducing the direct object before the verb. That is not to say that it is absolutely necessary to have spent years on classical chinese to be able to translate modern texts (although it can only help): this use of jiang is recorded in modern language dictionaries, and the grammar clearly distinguishes the constructions jiang + nominal expression, which is the equivalent of ba introducing the object of a verb, and jiang + verb, where it indicates a future tense. 

Chinese novels are of a truly mediocre quality. Fortunately, the Francophone reader is also offered perfectly good translations. But even in these, certain translation choices are open to dispute or discussion; indeed, a translation problem can sometimes be the occasion for interesting observations on the narrative techniques employed by the novelist.

As an example, we have chosen the remarkable novel by Yu Hua, Xu Sanguan mai xue ji (1996), translated into French by Nadine Perront under the titles Le Vendeur de sang (Paris, Actes Sud, 1997) (to be published in English as Chronicle of a Blood Merchant). This translation is good overall, entirely faithful as far as the meaning is concerned and generally close to the style of the original; it is a cause of genuine joy that a text of this quality has not been "spoiled" in the transition from Chinese to French. In the detail, however, it seems to me that certain parts could have been rendered better (which, after all, is inevitable: as I have already said, I am aware that translators of 300-page novels cannot always be at their best, above all that they cannot grant to each individual passage the same time that critics can afford).

Le Vendeur de sang is the history of a very simple man, Xu Sanguan, who, at various moments of his life, sells his blood in order to get by in critical situations, or even just to survive. In China, where the idea of parting with one's blood goes against traditional conceptions of longevity and health, the authorities reward "donors" in order to get people to give blood. (The novel takes on a particular resonance at a time when we know that millions of Chinese have been infected with the Aids virus following ill-fated transfusions). In the passage that we are going to examine, A Fang and Gen Long, two acquaintances of Xu Sanguan who are already very experienced in "selling" blood, accompany him on his first visit to the hospital, exhorting him in particular to drink copious quantities of water beforehand, because, according to them, "when you drink lots of water, your blood increases in proportion in your body". The extract is taken from page 16 of the translation by N. Perront:

Ils jetèrent [le seau] dans le puits, il heurta l'eau avec un bruit de gifle, et ils le remontèrent. A Fang et Gen Long burent chacun deux bols, et $\mathrm{A}$ Fang passa le sien à $\mathrm{Xu}$ Sanguan, qui en but un. Ils l'exhortèrent à boire davantage, et il prit encore deux gorgées d'un autre bol avant de verser le reste dans l'eau.

- J'ai une petite panse à pisse, dit-il. Je n'en peux plus.

A leur arrivée dans la salle des dons de sang, ils avaient tous les trois le visage cramoisi sous l'effort. Ils marchaient à petits pas précautionneux, comme s'ils étaient sur le point d'accoucher. A Fang et Gen Long, qui portaient les pastèques, marchaient encore plus lentement que Xu Sanguan. Ils se cramponnaient aux cordes de leur palanche pour empêcher les fardeaux d'osciller. Mais les couloirs de l'hôpital étaient étroits, et des gens heurtaient parfois les palanches en passant à côté d'eux, elles ballottaient, et l'eau qui ballonnait leurs ventres ballottait en cadence. La bouche tordue par la douleur, les deux hommes restaient alors cloués sur place et attendaient, sans oser faire un geste, que leurs fardeaux se fussent stabilisés pour se remettre en marche avec lenteur.

[They threw [the bucket] into the well, it hit the water like a slap in the face, and they hauled it back up. A Fang and Gen Long each drank two bowls, then A Fang passed his to Xu Sanguan, who drank one. They urged him to drink more, and he took another two gulps before throwing the rest back into the water.

-"I only have a small piss pot", he said. "I can't drink any more."

When they got to the blood donor room, all three had gone crimson in the face from the effort. They took small, wary steps, as if they were about to give birth. A Fang and Gen Long, who were carrying watermelons, were walking even more 
slowly than Xu Sanguan. They clutched the ropes of their yokes to stop the loads from swinging. But the hospital corridors were narrow, and people sometimes brushed against the yokes as they passed by, they wobbled, and the water welling up in their bellies wobbled in rhythmic time. Their mouths distorted with pain, the two men then stood rooted to the spot and waited, not daring to make a single move, until their loads would steady and they could start, slowly, walking again.]

In parts, the translation by N. Perront seems to me too refined. The tone of the Chinese text is that adopted by popular storytellers, sometimes by children's counting rhymes, with short and simple sentences, numerous repetitions, expressions full of imagery, plenty of onomatopoeia, and in this excerpt the French version is sometimes out of tune with this. In particular, the translation does not always reflect the vocabulary and the cultural level of the narrator. "Cramoisi» ("crimson in the face"), "en cadence» ("in rhythmic time"), «cloués sur place» ("nailed to the spot"), as well as the imperfect subjunctive «se fussent stabilisés» ("until their loads would steady"), seem to me turns of phrase that are too elegant here. The translation «comme s'ils étaient sur le point d'accoucher» ("as if they were about to give birth") presents a less powerful image than the original, which says «comme (une femme) grosse de dix mois» ("like a woman ten months' pregnant"). On the other hand, the alliteration «ballottaient»/«ballonnait» ("wobbled"/"welling up") is well worked and perfectly renders the onomatopoeia zhang gugu (even if, on a strictly semantic level, "ballonnement" and "ballottement" are two phenomena that are perhaps not totally compatible...). «Panse à pisse» ("piss pot") for niaoduzi also offers an amusing alliteration, which matches the tone of the narration (even if there is no alliteration in niaoduzi); at the same time, however, the word is repeated on several occasions in the novel and ends up becoming rather heavy. Here, the translator has perhaps tried for something too good. "Vessie» ("bladder") would undoubtedly have sufficed, for if pangguang, the more common word for «vessie» in Chinese, was perhaps too studied (too medical) for Xu Sanguan and his fellows, «vessie» is common usage in French, and we should also note that the French «pisse» is more vulgar than niao in Chinese.

21 At this juncture, a reflection on the status of the narrator is useful. The narrator of $L e$ Vendeur de sang is distinguished very clearly from the author of the book (Yu Hua): his tone is much less that of the intellectual, or of the novelist, than that of the popular raconteur. In other words, Yu Hua employs a narrator who at the cultural level is much closer to the (other) characters of the story than to the author himself (in contrast to the "I" of Lu Xun, for example). It has to be underlined that this process is certainly deliberate, as the narrator is remarkably consistent throughout the novel, at least in the Chinese version: in the French version, because of the variations in the language level mentioned above, the narrator appears less typecast.

Still on the language level, gongxueshi poses an interesting translation problem. The translation proposed, «blood donor room», is a little regrettable, as we are not dealing here with "donating", but with "selling" blood; «salle de prise de sang» ("blood-giving room") would have been better from this point of view. However, I would suggest «salle de transfusion» ("transfusion room"): agreed, this expression may seem too formal in this context, but after all, this is also the case with gongxueshi, a relatively technical word that stands out strongly, also in Chinese, in a narrative that uses extremely simple vocabulary. This translation is logical, however, if one puts oneself in the shoes of the characters: Xu Sanguan's two companions are in the habit of "selling" their blood, and even if they are somewhat uncouth, they certainly know the term used in 
hospital for the transfusion room. Moreover, it is easy to imagine that the name of the room appears on a sign on the door, a sign that our heroes would know or recognise in passing.

Furthermore, the translation «salle de transfusion» can itself be explained by the particular status of the narrator. The latter not only seems relatively uncouth himself, he is also only a simple outside observer. He contents himself with reporting the words and deeds of the characters (primarily Xu Sanguan), and the few descriptions that he makes of their internal life are simple inferences from their behaviour (there is no internal focus in Le Vendeur de sang). In other words, the narrator is a kind of idle onlooker, or travelling companion, who falls into step with the characters and relates, without the slightest critical reflection and in their own words, what they do and say. Thus, in the scene translated above, the narrator follows the three friends all the way in to the transfusion room-and "passes", like them, the sign bearing the characters gongxueshi which denotes this room: he sees the inscription, and the use of this technical word is thus normal here.

This example reveals that, in the most interesting cases, the shift between the original Chinese and the translated version can effectively reveal the techniques employed, consciously or unconsciously, by the author. In other words, the confrontation of the original with the translation sometimes allows us to comprehend more easily the way in which the narrative works and can be highly instructive for literary criticism, particularly in a narratological (structural) approach. This example also demonstrates that a certain familiarity with the processes and classifications of literary analysis can be useful in translation work.

If, in the case of languages as different as Chinese and French (or English), disparities between the original and the translation are inevitable (and can, on occasion, be instructive), the responsibility of the translator is to reduce them to a minimum in order to present the reader with as faithful a version as possible. This presupposes a large number of skills: mastery of the source and target languages, refusal to take the easy option, literary sensibility, intellectual rigour (and, I would be tempted to add, moral rigour). For when the most elementary skills are lacking, as is unfortunately the case with Les Lumières de Hong Kong, the translation becomes a betrayal of the original text, a disservice not only to the author but also to Chinese literature in general. Western readers, if they are not familiar with Chinese, cannot know that the weaknesses of these distorted texts that are offered to them are not to be ascribed to the author, but to the translator. In conclusion, let us remember that translation recall is a demanding craft, and a veneer of language and a few dictionaries are certainly not enough to make a good translator. 